\title{
Establishing Sampling Procedures in Lake Cores for Subsurface Biosphere Studies: Assessing In Situ Microbial Activity
}

\author{
by Aurèle Vuillemin, Daniel Ariztegui, Crisogono Vasconcelos, and
}

doi: 10.2204/iodp.sd.10.04.2010

the PASADO Scientific Drilling Party

\section{Introduction}

Sub-recent sediments in modern lakes are ideal to study early diagenetic processes with a combination of physical, chemical, and biological approaches. Current developments in the rapidly evolving field of geomicrobiology have allowed determining the role of microbes in these processes (Nealson and Stahl, 1997; Frankel and Bazylinski, 2003). Their distribution and diversity in marine sediments have been studied for some years (Parkes et al., 1994; D’Hondt et al., 2004; Teske, 2005). Comparable studies in the lacustrine realm, however, are quite scarce and mainly focused on the water column (Humayoun et al., 2003) and/or very shallow sediments (Spring et al., 2000; Zhao et al., 2007). Thus, there is a need to determine the presence of living microbes in older lacustrine sediments, their growth, and metabolic paths, as well as their phylogenies that seem to differ from already known isolates.

During the PASADO (Potrok Aike Maar Lake Sediment Archive Drilling Project) ICDP (International Continental

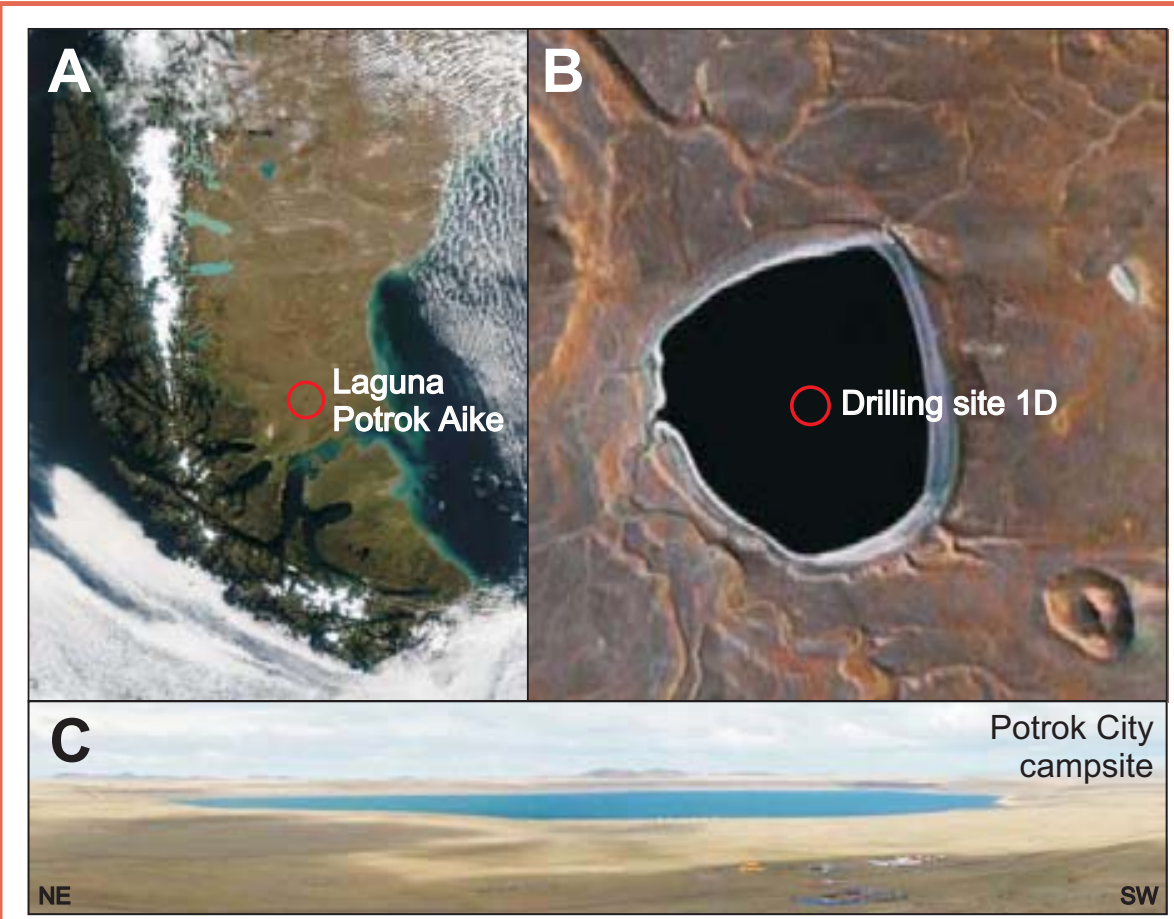

[A] Satellite image of Laguna Potrok Aike located in southernmost continental Patagonia, north of the Strait of Magellan, from http://www.zonu.com; [B] close-up of the lake showing the position of the drilling site discussed here, from http://earth.google.com; [C] panoramic view of the lake site with the field camp in the foreground.
Scientific Drilling Program) drilling, more than 500 meters of sedimentary cores were retrieved from this crater lake (Zolitschka et al., 2009). A 100-m-long core was dedicated to a detailed geomicrobiological study and sampled in order to fill the gap of knowledge in the lacustrine subsurface biosphere.

Here we report a complete in situ sampling procedure that aims to recover aseptic samples as well as determining active in situ biological activity. Preliminary results demonstrate that these procedures provide a very useful semi-quantitative index which immediately reveals whether there are biologically active zones within the sediments.

\section{The PASADO Project}

Laguna Potrok Aike is a 770-ka-old maar lake located at $51^{\circ} 58^{\prime} \mathrm{S}$ and $70^{\circ} 22^{\prime} \mathrm{W}$ in the Santa Cruz Province, Argentina, within the 3.8-Ma-old Pali Aike Volcanic Field (Fig. 1; Zolitschka et al., 2006). Although annual precipitation ranging between $200 \mathrm{~mm}$ and $300 \mathrm{~mm}$ gives a semi-arid character to the area, the lake is presently the only permanently water-filled lacustrine system in the southeastern Patagonian steppe. Today it has a maximum diameter of $3.5 \mathrm{~km}$, a total surface of $7.74 \mathrm{~km}^{2}$, and a maximum water depth of $100 \mathrm{~m}$. The lake regime is polymictic, and the water-column is non-stratified with an anoxic sedimentwater interphase.

A seismic study of this lacustrine basin showed a thick sedimentary sequence (Anselmetti et al., 2009; Gebhardt et al., in review) that was the target of the PASADO project. This international research initiative had a key objective: quantitative climatic and environmental reconstruction of this remote area through time. The multiproxy study also provides unique material to initiate, for the first time in an ICDP project, a systematic study of the living lacustrine subsurface environment. From a total of 533 meters of sediment cores recovered at $100 \mathrm{~m}$ 
water depth (Fig. 1), a one-meter-long gravity core PTA-1I and the 97-m-long hydraulic piston core PTA-1D were sampled following a newly established strategy to obtain aseptic samples for geomicrobiological studies.

\section{Sampling Procedure}

A procedure was designed to minimize contamination risks in the field and laboratory. The size and configuration of the drilling platform prevented the setting up of a sampling laboratory with maximum conditions of asepsis. Thus, the retrieved cores were transported every $90 \mathrm{~min}$ from the platform to a laboratory in the campsite where they were sampled (Fig. 2). The liners of hydraulic cores were first disinfected with isopropanol and then sprayed with fungicide. Thereafter, cut in the liner using a portable circular saw every one or two meters and at higher resollution for the upper $15 \mathrm{~m}$ (Fig.3). Conversely, in the gravity core twenty windows were cut at 5 -cm spacing in the empty liner and sealed with strong adhesive tape prior to coring. This latter technique facilitated opening windows and allowed sampling quickly at a higher resolution. Samples from these windows were immediately chemically fixed and/or frozen, optimizing the preservation of their initial conditions for further analyses.

A rapid biological activity test, which is commercially available for industrial hygiene monitoring, was applied immediately after coring in order to test for microbial activity in the sediments. In situ adenosine-5'-triphosphate (ATP) measurements were taken as an indication of living organisms within the sediments. The presence of ATP is a marker molecule for metabolically active cells (Bird et al., 2001), since it is not known to form abiotically. ATP can be easily detected with high sensitivity and high specificity using an enzymatic assay (Lee et al., 2010).

$\mathrm{ATP}+$ luciferin $+\mathrm{O}_{2} \rightarrow \mathrm{AMP}+$ oxyluciferin $+\mathrm{PPi}+\mathrm{CO}_{2}+$ light and pyrophosphate (PPi) while luciferin is oxidized. Light is emitted as a result of the reaction, and the light is detected by a photomultiplier. We used the Uni-Lite ${ }^{\circledR} \mathrm{NG}$ Luminometer (Biotrace International Plc, Bridgend, U.K.), in combination with the "Clean-Trace" and "Aqua-Trace" swab kits (3M, U.S., Fig. 3E). The sensitivity of the test is on the order of $10^{-20}$ moles of ATP per mL of water, corresponding to a standard of 5 cells of Escherichia coli as expressed in RLU (relative luminescence units). This handheld device was previously tested at the Geomicrobiology Laboratory, ETH Zurich (Switzerland), where it was determined that this method could be applied on geological material such as rock surfaces and other environmental biofilms. It was also successfully used for fast and accurate measurements of life activity for freshly retrieved cores in lithified sediments of the IODP

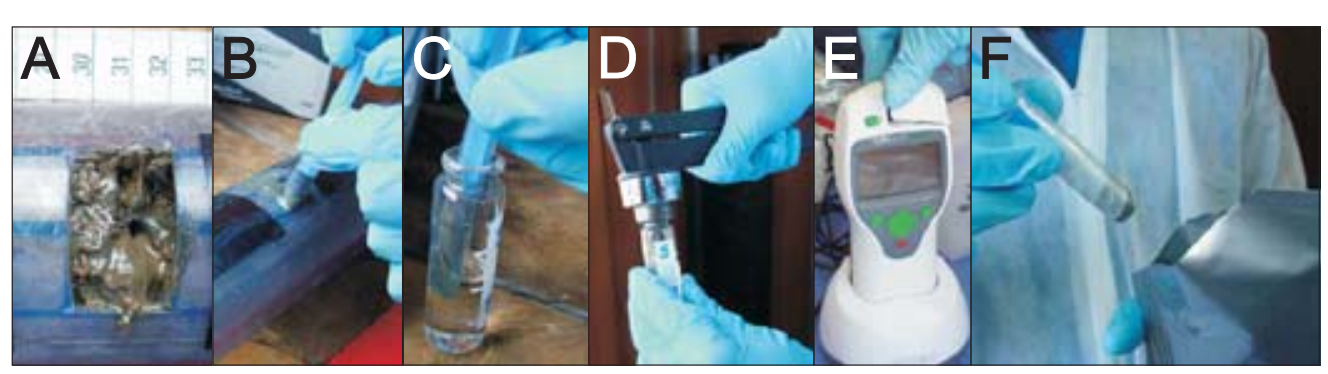

Expedition 310 in Tahiti (Camoin et al., 2007). The performance of this instrument in fresh sediments was uncertain, however, and to our knowledge this is the first time that it was successfully applied to lacustrine sediments. Additionally, the application of

Figure 3. [A] Window cut for sampling; [B-D] sampling for methane headspace determinations; [E] preparation of the sample for in situ ATP measurements: sample is mixed with deionized water prior to centrifugation, then tested with the Uni-Lite ${ }^{\circledR} \mathrm{NG}$ water tester (shown); and [F] storage of the remaining sediment for cell culture. Refer to text this test to water samples can aid in the evaluation of for details. 
the degree of contamination of the drilling water which percolates along the inside of the core liner.

Figure $3 \mathrm{~A}-3 \mathrm{~F}$ summarizes the sequence and sampling procedures established in this project. Part of the sampling required precise volumes that were obtained using sterile syringes. Thus, samples of $3 \mathrm{~mL}$ and $5 \mathrm{~mL}$ of sediment were extracted from freshly opened windows using these syringes whose narrow tips were cut off in order to collect "minicores” (Fig. 3B). The first extracted sample was designated for methane analyses because of its immediate release into the environment due to volume expansion when exposed to ambient pressure. Hence, a portion $(3 \mathrm{~mL})$ of this first sample was chemically stabilized using 10 mL of $2.5 \%$ sodium hydroxide, and then sealed in vials for headspace analysis (Figs. 3C and 3D). The sediments were further sampled for different techniques using 5-mL syringes and portioned out as follows: the first 1-mL portion of sample was placed in an Eppendorf tube and kept frozen for further DNA extraction; a second 1-mL portion was chemically fixed in formaldehyde (final concentration, $2 \%$ ) for DAPI (4',6-diamidino-2-phenylindole) cell count; a third 1-mL portion of the sediment was mixed with 1-mL of deionized water in an Eppendorf tube and centrifuged for five minutes. Commercially available water testers (Biotrace International) were carefully submerged in the supernatant, and ATP content was measured with the Uni-Lite ${ }^{\circledR}$ NG luminometer as an index of in situ microbial activity (Fig. 3E). The remaining sediment in the syringe was coated with plastic foil and hermetically sealed into alu- minum foil bags (Fig. 3F). These bags were flushed with nitrogen (to prevent oxidation) prior to sealing with a heating device. These samples can be further used for microbial culture experiments back at the home laboratory. Once the sampling was accomplished, the windows were sealed with strong adhesive tape. This sampling procedure was carried out non-stop over a 48-hour period. A comparable sampling procedure for marine sediments can be found in Bird et al. (2001).

\section{Assessing In Situ Microbial Activity in Sediments}

The presence of nutrients as energy sources is critical, promoting an active behavior of the inner microbial communities within sediments. When certain nutrient concentrations are below a threshold, microbial metabolism and population density are lowered progressively as these microbial communities enter in dormant state. Thus, microbial communities in deep sediments can be considered as mainly oligotrophic and dormant.

The 97-m-long sediment core retrieved from Laguna Potrok Aike provided us the opportunity to identify a transition from a weak but active to a dormant state of microbial communities as reflected by in situ ATP measurements (Fig. 4A). These results were further compared with those from DAPI counting on the fixed samples carried out several months later in the laboratory (Fig. 4B). The DAPI fluorochrome dyes DNA without distinction -active, dormant, and dead cells, either eukaryote or prokaryote-and it is considered as a semi-quantitative index of cell density within the sediment. ATP and DAPI datasets, however, show an increasing trend from the sediment surface to $\sim 6-\mathrm{m}$ depth within sediments mainly composed of black mud and subject to gas expansion. The DAPI and ATP trends throughout depth suggest an exponential decrease in microbial activity that is most probably linked to a progressive compaction and gradual nutrient depletion within the sediments. There is, however, detectable microbial activity down to 40-50 $\mathrm{m}$ and recoverable DNA down to $60 \mathrm{~m}$ sediment depth.

The sediments recovered from Laguna Potrok Aike are dominantly argillaceous but are occasionally interrupted by coarser sandy layers associated to slumps triggered by erosional and/or volcanic activities (Zolitschka et al., 2009). The latter are very important since allochthonous organic matter is harder to degrade, and microbial pres-ervation is highly dependent on grain size. Different sediment features further
Figure 4. [A] The first ATP measurements were taken in an average of an hour and a half after each core recovery. They are considered as excellent indicators of in situ microbial activity. Noise was measured around 30 RLU (relative luminescence unit); [B] DAPI cell count provides a quantification of DNA present in the same samples; [C] second ATP measurements performed ten months later to test for eventual shifts in microbial activity. Although ATP indexes of active layers increased up to 20 -fold, the originally nutrient-depleted layers remained inactive. Insert [D] shows a picture of mold (white arrows) which developed after exposure of the sediments to oxygen and pressure temperature (PT) ambient conditions. This partially caused the increased ATP values for the second run of measurements. 
constrain microbial activity, as they provide colonization niches. Although microbial communities may adapt to trophic changes by shifting either their activity and/or dominant species, they are still highly representative of the lake catchment and their dominating climate. Ongoing multiproxy analyses of these cores will allow char-acterizing the sedimentary sequence and provide the critical grounds to interpret the results of the observed microbial behavior.

\section{Validating In Situ ATP Measurements}

Metabolic microbial activity can change drastically when samples are exposed to ambient temperature and pressure, light, and oxygen. In order to identify and possibly quantify the magnitude of these metabolic changes, a second set of ATP measurements was produced ten months after cores were retrieved (Fig. 4C). Both results indicate very similar distributions of microbial activity displaying the highest values at the same depths. In spite of the liner disinfection and the sealing of the sampling windows, mold had grown superficially on some windows, as shown in Figure 4D. The development of mesophilic aerobic microorganisms explains the comparatively higher ATP index of this second data set. These measurements warn about the omnipresent risks of contamination during sampling and further storage of the samples. They secondarily provide information about the nutrient resources of the sediments and their accessibility and use by microbes. Thus, this comparison between in situ and later ATP measurements highlights the relevance of the immediate measurement of microbiological living activity in the field. The comparison presented here between ATP values quickly obtained with a handset device further validates those in situ results produced by more established and tedious analyses such as DAPI cell counting of microbial cells.

\section{Future Improvements in Detecting the Living Biosphere in Lake Sediments}

Lacustrine systems gather widely diverse water types such as brackish (Banning et al., 2005), acidic (Chan et al., 2002), hypersaline (Cytryn et al., 2000), or alkaline (Jones et al., 1998), among others. Each of them contains very different sediment and associated microbial assemblages. Understanding trophic states within the water columns and the sediments is essential to reconstructing past climates (Nelson et al., 2007) as well as to managing anthropogenic impact on modern lakes (Ye et al., 2009).

The assessment of microbial activity presented here provides information on various ongoing organic matter mineralization processes in the sediments and helps to understand the influence of microbes during early diagenesis. Our procedure can be easily applied as routine, adding valuable microbiological information that is complementary and relevant to several standard lacustrine proxies such as the stable isotope composition of authigenic carbonates and organic matter. Thus, the Uni-Lite ${ }^{\circledR}$ NG ATP tester is an excellent alternative to previously proposed complex ATP extractions (Stoeck et al., 2000; Bird et al., 2001; Nakamura and Takaya, 2003).

We are confident that the sampling protocol proposed here will allow scientists to sample cores in other ICDP projects with minimal contamination risks. It further points towards new research avenues and technical developments to better detect microbial activity and metabolic functions of the subsurface lacustrine biosphere.

\section{Acknowledgements}

We are indebted to S. Templer (MIT, Boston, U.S.) for productive discussions and introducing us to geomicrobiological sampling techniques. C. Recasens, R. Farah (University of Geneva, Switzerland) and C. Mayr (University of Erlangen, Germany) are kindly acknowledged for their help during field sampling. We thank the PASADO Scientific Drilling Party for fruitful discussions and help during drilling operations. B. Zolitschka's comments on an earlier version of the manuscript are specially acknowledged.

Funding for drilling was provided by the ICDP, the German Science Foundation (DFG), the Swiss National Funds (SNF), the Natural Sciences and Engineering Research Council of Canada (NSERC), the Swedish Vetenskapsradet (VR), and the University of Bremen. We are also grateful to the Swiss National Science Foundation (Grant $200020-119931 / 2$ to D. Ariztegui) and the University of Geneva, Switzerland.

\section{References}

Anselmetti, F.S., Ariztegui, D., De Batist, M., Gebhardt, C., Haberzettl, T., Niessen, F., Ohlendorf, C., and Zolitschka, B., 2009. Environmental history of southern Patagonia unraveled by the seismic stratigraphy of Laguna Potrok Aike. Sedimentology 56/4:873-892, doi:10.1111/j.1365-3091.2008. 01002.x.

Banning, N., Brock, F., Fry, J.C., Parkes, R.J., Hornibrook, E.R.C., and Weightman, A.J., 2005. Investigation of the methanogen population structure and activity in a brackish lake sediment. Environ. Microbiol., 7:947-960, doi:10.1111/j.14622920.2004.00766.x.

Bird, D.F., Juniper, S.K., Ricciardi-Rigault, M., Martineu, P., Prairie, Y.T., and Calvert, S.E., 2001. Subsurface viruses and bacteria in Holocene/Late Pleistocene sediments of Saanich Inlet, BC: ODP Holes 1033B and 1034B, Leg 169S. Mar. Geol., 174:227-239, doi:10.1016/S0025-3227(00)00152-3.

Camoin, G.F., Iryu, Y., McInroy, D.B., and Expedition 310 Scientists, 2007. Proc. IODP, 310: College Station, TX (Integrated Ocean Drilling Program Management International, Inc.).

Chan, O.C., Wolf, M., Hepperle, D., and Casper, P., 2002. Methanogenic archaeal community in the sediment of an artificially partitioned acidic bog lake. FEMS Microbiol. Ecol., 42:119-129, doi:10.1111/j.1574-6941.2002.tb01001.x. 
Cytryn, E., Minz, D., Oremland, R.S., and Cohen, Y., 2000. Distribution and diversity of Archaea corresponding to the limnological cycle of a hypersaline stratified lake (Solar Lake, Sinai, Egypt). Appl. Environ. Microbiol., 66:3269-3276, doi:10.1128/AEM.66.8.3269-3276.2000.

D’Hondt, S., Jorgensen, B.B., Millet, D.J., Batzke, A., Blake, R., Cragg, B.A., Cypionka, H., Dickens, G.R., Ferdelman, T., Hinrichs, K.-U., Holm, N.G., Mitterer, R., Spivack, A., Wang, G., Bekins, B., Engelen, B., Ford, K., Gettemy, G., Rutherford, S.D., Sass, H., Skilbeck, C.G., Aiello, I.W., Guèrin, G., House, C.H., Inagaki, F., Meister, P., Naehr, T., Niitsuma, S., Parkes, R.J., Schippers, A., Smith, D.C., Teske, A., Wiegel, J., Padilla, C.N., and Acosta, J.L.S., 2004. Distributions of microbial activities in deep subseafloor sediments. Science, 306: 2216-2221, doi:10.1126/science.1101155.

Frankel, R.B., and Bazylinski, D.A., 2003. Biologically induced mineralization by bacteria. Biomineralization, 54:95-114.

Gebhardt, C.A., De Batist, M., Niessen, F., Anselmetti, F.S., Ariztegui, D., Kopsch, C., Ohlendorf, C., and Zolitschka, B., in review. Origin and evolution of Laguna Potrok Aike maar (Southern Patagonia, Argentina) as revealed by seismic refraction and reflection data. Geophys. J. Intl.

Humayoun, S.B., Bano, N., and Hollibaugh, J.T., 2003. Depth distribution of microbial diversity in Mono Lake, a meromictic soda lake in California. Appl. Environ. Microbiol., 69:1030-1042, doi:10.1128/AEM.69.2.1030-1042.2003.

Jones, B.E., Grant, W.D., Duckworth, A.W., and Owenson, G.G., 1998. Microbial diversity of soda lakes. Extremophiles, 2:191-200, doi:10.1007/s007920050060.

Lee, H.J., Ho, M.R., Bhuwan, M., Hsu, C.Y., Huang M.S., Peng H.L., and Chang H.Y., 2010. Enhancing ATP-based bacteria and biofilm detection by enzymatic pyrophosphate regeneration. Analytical Biochemistry, 399:168-173, doi:10.1016/j. ab.2009.12.032.

Nakamura, K.-I., and Takaya, C., 2003. Assay of phosphatase activity and ATP biomass in tideland sediments and classification of the intertidal area using chemical values. Mar. Poll. Bull., 47:5-9, doi:10.1016/S0025-326X(02)00471-X.

Nealson, K.H., and Stahl, D.A., 1997. Microorganisms and biogeochemical cycles: what can we learn from layered microbial communities? Rev. Mineral. Geochem., 35:5-34.

Nelson, D.M., Ohene-Adjei, S., Hu, F.S., Cann, I.K.O., and Mackie, R.I., 2007. Bacterial diversity and distribution in the Holocene sediments of a northern temperate lake. Microb. Ecol., 54:252-263, doi:10.1007/s00248-006-9195-9.

Parkes, R.J., Cragg, B.A., Bale, S.J., Getliff, J.M., Goodmann, K., Rochelle, P.A., Fry, J.C., Weightman, A.J., and Harvey, S.M., 1994. Deep bacterial biosphere in Pacific Ocean sediments. Nature, 371:410-413, doi:10.1038/371410a0.

Spring, S., Schulze, R., Overmann, J., and Schleifer, K.-H., 2000. Identification and characterization of ecologically significant prokaryotes in the sediment of freshwater lakes: molecular and cultivation studies. FEMS Microbiol. Rev., 24:573-590, doi:10.1111/j.1574-6976.2000.tb00559.x.

Stoeck, T., Duineveld, G.C.A., Kok, A., and Albers, B.P., 2000. Nucleic acids and ATP to assess microbial biomass and activity in a marine biosedimentary system. Mar. Biol., 137:1111-112, doi:10.1007/s002270000395.

Teske, A.P., 2005. The deep subsurface biosphere is alive and well.
Trends Microbiol., 13(9):402-404, doi:10.1016/j.tim.2005. 07.004 .

Ye, W., Liu, X., Lin, S., Tan, J., Pan, J., Li, D., and Yang, H., 2009. The vertical distribution of bacterial and archaeal communities in the water and sediment of Lake Taihu. FEMS Microbiol. Ecol., 70:263-276, doi:10.1111/j.1574-6941.2009.00761.x.

Zhao, X., Yang, L., Yu, Z., Peng, N., Xiao, L., Yin, D., and Qin, B., 2007. Characterization of depth-related microbial communities in lake sediments by denaturing gradient gel electrophoresis of amplified 16S rRNA fragments. J. Environ. Sci., 20:224230, doi:10.1016/S1001-0742(08)60035-2.

Zolitschka, B., Anselmetti, F., Ariztegui, D., Corbella, H., Francus, P., Ohlendorf, C., Schäbitz, F., and the PASADO Scientific Drilling Team, 2009. The Laguna Potrok Aike Scientific Drilling Project PASADO (ICDP Expedition 5022). Sci. Drill., 8:29-34.

Zolitschka, B., Schäbitz, F., Lücke, A., Clifton, G., Corbella, H., Ercolano, B., Haberzettl, T., Maidana, N., Mayr, C., Ohlendorf, C., Oliva, G., Paez, M.M., Schleser, G.H., Soto, J., Tiberi, P., and Wille, M., 2006. Crater lakes of the PaliAike Volcanic Field as key sites of paleoclimatic and paleoecological reconstructions in southern Patagonia, Argentina. J. S. Am. Earth Sci., 21:294-309, doi:10.1016/j. jsames.2006.04.001

\section{Authors}

Aurèle Vuillemin and Daniel Ariztegui, Section of Earth \& Environmental Sciences, University of Geneva, Rue des Maraîchers 13, CH-1205 Geneva, Switzerland, e-mail: aurele. vuillemin@unige.ch, daniel.ariztegui@unige.ch

Crisogono Vasconcelos, Geological Institute, ETH Zürich, Sonneggstr. 5, 8092 Zürich, Switzerland, e-mail: cris.vasconcelos@erdw.ethz.ch

\section{and the PASADO Scientific Drilling Party}

\section{Photo Credits}

Figures 1C, 2A-C, 3A-F, and 4D by Aurèle Vuillemin

\section{Related Web Links}

http://www.icdp-online.org/

http://www.pasado.uni-bremen.de

http://www.biotraces.com

http://earth.eo.esa.int/satelliteimages/

http://www.zonu.com

http://earth.google.com 